\title{
Enrichment Planting in Secondary Forests: a Promising Clean Development Mechanism to Increase Terrestrial Carbon Sinks
}

\author{
$\underline{\text { Alain Paquette }}^{1}, \underline{\text { Jessica Hawryshyn }}^{2}, \underline{\text { Alexandra Vyta Senikas }}^{2}$, and Catherine Potvin $^{2,3}$
}

\begin{abstract}
With the increasing need to reduce greenhouse gas concentrations, afforestation and reforestation $(\mathrm{A} / \mathrm{R})$ projects are being implemented under the Kyoto Clean Development Mechanism $(\mathrm{CDM})$ and under the voluntary carbon $(\mathrm{C})$ market. The specific objective of $\mathrm{A} / \mathrm{R} \mathrm{C}$ projects is to enhance terrestrial sinks. They could also provide low-income communities in developing countries with a source of revenue, as well as a number of ecological and social services. However, feasibility issues have hindered implementation of A/R CDMs. We propose enrichment planting (EP) in old fallow using high-value native timber species as a land-use alternative and a small-scale $\mathrm{C}$ projects opportunity. We present EP in the context of ongoing work in a poor indigenous community in eastern Panama. We consider economic risks and advantages and concordance with existing modalities under the compliance market. The potential storage capacity for EP at the site of our study was $\sim 113 \mathrm{Mg} \mathrm{C} \mathrm{ha}^{-1}$, which is comparable to other land uses with high $\mathrm{C}$ storage, such as industrial teak plantations and primary forest. Because secondary forests show high aboveground biomass production, $\mathrm{C}$ projects using EP could harness large amounts of atmospheric $\mathrm{C}$ while improving diversity. Carbon projects using EP can also provide high levels of social, cultural, and ecological services by planting native tree species of traditional importance to local communities and preserving most of the secondary forest's ecological attributes. Therefore, EP planting could be considered as a way to promote synergies between two UN Conventions: climate change and biodiversity.
\end{abstract}

\section{SÍNTESIS}

Con la necesidad apremiante de reducción de los gases de efecto invernadero, proyectos de aforestación y reforestación (A/R) pueden implementarse bajo el Mecanismo de Desarrollo Limpio del Protocolo de Kyoto (MDL) o en el contexto del mercado voluntario. El objetivo especifico de los mercados de carbono, voluntario o de compromiso, es de estimular el almacenamiento de carbono terrestre. Además, los proyectos de carbono podrían presentar una oportunidad para cambiar prácticas de uso de la tierra y proteger la biodiversidad mientras se provee un ingreso a las comunidades de países en desarrollo para mantener servicios ambientales. Proponemos un enriquecimiento de plantación cubierta (EP) en rastrojos o bosques secundarios utilizando especies de maderas nativas preciosas como alternativa forestal y proyecto de carbono a pequeña escala. Los diferentes aspectos de implementación del A/R-MDL actual están tomados en cuenta. Discutimos la EP en el contexto de investigaciones continuas en la comunidad indígena IpetíEmberá en Panamá-Este. En nuestro sitio, el potencia de almacenamiento de carbono para la EP podría ser de $113 \mathrm{Mg} \mathrm{Cha}^{-1}$, lo cual es comparable a otros usos del suelo como plantaciones de teca y bosque primario. Como los rastrojos presentan una alta producción de biomasa, proyectos de carbono con EP podría acumular cantidades grandes de carbono atmosférico mientras se proveen beneficios socio-económicos. Al mismo tiempo EP podría mantener la estructura ecológica del bosque secundario y la biodiversidad promoviendo sinergias entre dos convenios: el de Biodiversidad y el de cambios climáticos.

Key Words: biodiversity; carbon sequestration; clean development mechanism; enrichment planting; indigenous communities; payments for environmental services; secondary forests 


\section{INTRODUCTION}

Global environmental attention has increasingly focused on reducing the atmospheric concentration of greenhouse gas (GHG) out of concern for climate change. The Kyoto Protocol's ratification in February 2005 allowed industrialized countries to meet part of their commitment of GHG reduction by trading "Certified Emissions Reductions" (CERs) produced from carbon (C)-reducing or Cavoiding projects known as "Clean Development Mechanisms" (CDMs) (United Nations Framework Convention on Climate Change (UNFCCC) 2007) (see Table 1 for acronyms and definitions of CDM terms). These CDM projects are meant to help reduce atmospheric carbon dioxide $\left(\mathrm{CO}_{2}\right)$ while also stimulating sustainable development in developing countries (Minang et al. 2008, Takimoto et al. 2008). The CDM activities recognized in the first commitment period of the Kyoto Protocol include afforestation and reforestation (A/R) projects (UNFCCC 2007).

In Latin America and elsewhere, $\mathrm{A} / \mathrm{R}$ and "Payments for Environmental Services" (PES) projects could offer a way to change land-use patterns, increase $\mathrm{C}$ storage and stimulate sustainable development (Foley et al. 2007, Suyanto et al. 2007, Wunder and Albán 2008). However, a 3-year feasibility study of A/R CDMs in an indigenous community in eastern Panama found significant problems in its implementation (Coomes et al. 2008), as is also the case with many PES projects in the tropics (Wunder 2006). The financial costs and risks for the project were prohibitively high compared with the best alternative land use, cattle ranching. Although the total net revenue of the A/R CDM project was more profitable than cattle ranching, the annual revenue from cattle was higher in most years. The returns from the A/R CDM project would come mostly at the end of the 25-year term with the sale of the high-value teak (Tectona grandis) timber, making the potential economic gains distant and risky for asset-poor farmers. Given current economic circumstances and the scope of projects permitted under $\mathrm{A} / \mathrm{R} \mathrm{CDM}$, alternative methods of $C$ sequestration in the land-use sector are clearly necessary (Coomes et al. 2008). In order for $\mathrm{A} / \mathrm{R}$ CDM projects to be attractive, the projects must provide benefits and financial stability comparable to other profitable land uses such as cattle ranching (Ibarra Gené 2007, Potvin et al. 2007a).
Land-use changes, especially tropical deforestation, account for roughly $25 \%$ of global GHG emissions (International Panel on Climate Change (IPCC) 2001). The importance of tropical deforestation for the global $\mathrm{C}$ cycle has been highlighted recently (Houghton 2005). As a consequence, a negotiation began under the UNFCCC in 2005 to look at positive incentives to reduce emissions from deforestation and forest degradation (REDD) in developing countries (Gullison et al. 2007). This negotiation was stimulated by the publication of the Stern Review on the economics of climate change (Stern 2007) that presented REDD as one of the most costefficient ways to mitigate the atmospheric $\mathrm{CO}_{2}$ concentration. Decisions reached at the Conference of Parties to the UNFCCC in Bali in December 2007 confirm the renewed interest of climate change negotiators in the forest sector (Potvin and Bovarnick 2008). The Bali decisions opened the door to the inclusion of mechanisms to reward not only REDD, but also forest practices leading to incremental changes in $\mathrm{C}$ stocks. As negotiations are ongoing, modalities leading to the inclusion of REDD, or incremental changes in C stocks, have not yet been determined (Potvin and Bovarnick 2008). However, if REDD is associated with a form of direct payment or financial support, it could stimulate land-use changes maximizing $C$ stocks. Researchers have argued that if small-scale farmers are compensated in exchange for forest being protected, economic and social benefits would follow (Ibarra Gené 2007, Suyanto et al. 2007, Coomes et al. 2008).

Intact forests are disappearing worldwide, causing massive species extinctions (Dirzo and Raven 2003). Conversely, secondary forest is a rapidly increasing land-cover type in the tropics as a result of deforestation by logging and conversion to pasture and agricultural land (Hughes et al. 1999, Foley et al. 2007). Secondary forests have high rates of biomass productivity during early succession, and therefore, have the "potential to assimilate and store relatively large fractions of the $\mathrm{C}$ and nutrients that are lost during deforestation and land use phases" (Hughes et al. 1999:1892). One of the underlying causes of deforestation and forest degradation is the market's failure to adequately compensate landowners for the environmental services that their forests provide to society (Ibarra Gené 2007).

Here, we propose enrichment planting (EP) as a land-use alternative that provides an opportunity to 
Table 1. List of acronyms used in CDM literature (UNFCCC 2007).

\begin{tabular}{ll}
\hline \hline Acronym & Definition \\
\hline A/R & $\begin{array}{l}\text { Afforestation and reforestation. } \\
\text { A/R AMS }\end{array}$ \\
Simplified baseline and monitoring methodologies for small-scale afforestation and reforestation \\
project activities under the clean development mechanism. \\
Approved baseline and monitoring methodologies for afforestation and reforestation project \\
activities under the clean development mechanism. \\
Clean development mechanism. \\
CER & $\begin{array}{l}\text { Certified emissions reductions. } \\
\text { GHG }\end{array}$ \\
LULUCF & $\begin{array}{l}\text { Land use, land-use change and forestry. } \\
\text { PES }\end{array}$ \\
REDD & Rayments for environmental services. \\
UNFCCC & United Nations Framework Convention on Climate Change. \\
\hline
\end{tabular}

reduce emissions from deforestation and forest degradation (Dalle et al. 2006). Enrichment planting introduces valuable timber species in existing, but degraded, secondary forest (Aide et al. 2000, International Tropical Timber Organization (ITTO) 2002, Martinez-Garza and Howe 2003, Paquette et al. 2006a). By doing so, EP protects secondary forests and uses the thinned overstory as shelterwood, defined as residual forest cover under which natural or artificial regeneration is managed after a partial cut (Ashton and Peters 1999). Much like agroforestry and "domestic forest," EP combines both "artificial" planting and "natural" management of the existing forest matrix (shelterwood) by mimicking natural gap dynamics, and allows for the maintenance of a vegetation structure composed of different layers and complex assemblages of plants, thus retaining a forest character and associated biodiversity and ecological services (McComb et al. 1993, Hansen et al. 1995, Michon et al. 2007).

Enrichment planting can be successfully used to increase the value of secondary forests and prevent their conversion to other land uses, thus reducing deforestation (Montagnini et al. 1997, Dalle et al. 2006). We contend that EP could be an important land-use strategy in the context of the current international attempt to curb deforestation and forest degradation in developing countries. Enrichment planting projects present an interesting opportunity for $\mathrm{C}$ sequestration, currently under voluntary market frameworks and potentially under compliance markets in the future. In the present study, the $\mathrm{C}$ sequestration potential of $\mathrm{EP}$ is estimated and compared with that of other documented land uses. We focus on a current pilot project underway in eastern Panama to understand how C-offsetting projects can be established in a tropical indigenous community, as a science-based poverty alleviation and environmental conservation project.

\section{ECONOMIC FEASIBILITY AND CONCORDANCE WITH A/R CDM REGULATIONS}

Current "land use, land-use change and forestry" (LULUCF) A/R projects under Kyoto include 
native forest restoration, timber plantations, agroforests, and recovery of barren areas (Pearson et al. 2006). Various methodologies exist for A/R CDM projects. Small-scale A/R (A/R AMS) methodology is applicable to projects in lowincome communities sequestering no more than $8000 \mathrm{Mg} \mathrm{CO}_{2}$ year $^{-1}$, which can span between 200 and 1000 ha depending on species-related and environmental conditions (Pearson et al. 2006, UNFCCC 2006). Although concerns have been raised about the implementation of $A / R$ CDM projects in resource-poor communities (Minang et al. 2008), the main advantage of the A/R AMS methodology is that it uses a simplified baseline and monitoring methodology to minimize the transaction costs of the project. Thus, it renders small socially beneficial projects more competitive compared with large-scale forestry projects such as industrial teak plantations (Smith and Scherr 2003). Some examples of induced land-use change through PES, such as $C$ sequestration, have already demonstrated significant and lasting positive effects (DeClerck et al. 2006, Pagiola et al. 2007, Locatelli et al. 2008, Takimoto et al. 2008).

Currently, project areas for A/R CDMs must have been devoid of forest after 31 December 1989, with respect to the host country's forest definition to determine land eligibility (UNFCCC 2006), in effect excluding most EP projects as legitimate CDM alternatives. Yet, small-scale EP projects present economic advantages over other A/R AMS types. The area to be planted does not require lengthy and widespread clearing and preparation before planting, thus reducing the start-up costs of the project (Lugo 1997). As such, planting can occur almost immediately after the project has begun, thus shortening the time lapse to the reception of payments for $\mathrm{C}$ sequestration. Tending of an enrichment plantation is required for the first few years to clear the planted lines (Ådjers et al. 1995, Peña-Claros et al. 2002), but maintenance is subsequently limited to monitoring tree health and sustained growth, thus reducing labor costs in the future. Land preparation and tending can be carried out through local practices. By minimizing environmental disturbance, EP requires fewer initial costs and includes local communities from the outset of the project, therefore increasing its long-term economic viability. Much like mixedspecies plantations, by using several species and maintaining at least some of the biodiversity present in secondary forests, EP yields more diverse forest products than monospecific stands, thus reducing farmers' risks in unstable markets (Montagnini and Porras 1998). Furthermore, EP can benefit from additional certification for reaching environmental and socioeconomic goals (Pearson et al. 2006, Ibarra Gené 2007, Coomes et al. 2008). Lastly, it should be noted that although EP is also susceptible to some economic risks, for example fire hazard, these risks are shared by all forestry-type C-offset projects (Smith et al. 2000).

Although common in tropical EP literature, the success of this practice has been variable. Failures are generally attributed to insufficient stand preparation or tending, improper selection of planting stock, pest attacks, and high costs (ITTO 2002, Romell et al. 2008, Schulze 2008). Unfortunately, many ongoing projects do not report their results, rendering it impossible to learn from these experiences, even in the case of large projects such as those of the Face Foundation in Malaysia, Uganda, and Ecuador. Also, there is still much to be learned about the specifics of the many species that are available for planting (Davidson et al. 2002, Paquette et al. 2006b). Interestingly, the experience with EP in terms of increasing the wood volume and economic value of secondary forests has generally been more successful than in logged-over primary forests (ITTO 2002).

\section{CASE STUDY: ENRICHMENT PLANTING IN IPETÍ-EMBERÁ, PANAMA}

The Emberá indigenous community of IpetíEmberá is located in the watershed of Alto Bayano, in the Chepo District in the Province of Panama, Panama $\left(78^{\circ} 30^{\prime}-78^{\circ} 34^{\prime} \mathrm{W}, 8^{\circ} 55^{\prime}-9^{\circ} 00^{\prime} \mathrm{N}\right)$ (Tschakert et al.2007). The community landholding is composed of 3168 ha of communal land known as "tierra colectiva," which is subdivided in 1-100 ha "parcelas" managed by individual households. A socioeconomic study conducted in Ipetí-Emberá in 2004 indicates that, at the time, per capita net income was on average US\$200 (Tschakert et al. 2007), relying heavily on the use of natural resources.

Although agroforestry is a traditional Emberá agricultural practice, cattle ranching (Fig. 1) has become the fastest growing livelihood in this community, and is contributing to deforestation in the area and to global warming as part of a larger accumulative process (Kirby and Potvin 2007, Potvin et al. 2007b). Reforestation with native 
species has been examined in the CDM framework to see if positive externalities could be brought to the community (Potvin et al. 2007b). These externalities include increasing biodiversity through increased forest cover and long-term economic benefits in the form of valuable timber as well as non-timber products (Kirby and Potvin 2007, Tschakert et al. 2007).

In Ipetí, EP pilot projects were established in old fallows ("rastrojo alto"), which are young secondary forests following agricultural abandonment (Fig. 2). These forests are of low diversity and almost devoid of both timber and tree species traditionally used by the Emberás (Tschakert et al. 2007). The most probable use for these areas in the foreseeable future in Ipetí is either to let them grow with no silvicultural input to improve biodiversity and services, or to cut them for cattle ranching (Potvin et al. 2007b). Three EP plantations have been established since 2005 and nurseries were initiated for future plantations as small voluntary $\mathrm{C}$ projects for individuals or institutions wanting to offset their $\mathrm{CO}_{2}$ emissions.

The first plantation (September 2005; Fig. 2) had an experimental design composed of cleared strips of $1 \mathrm{~m}, 3 \mathrm{~m}$, and $6 \mathrm{~m}$ (two of each), with preserved strips of $6 \mathrm{~m}$ between them and 39-45 planted trees in each (245 trees in total). The original forest, now comprising the matrix between the planting strips, was $15 \mathrm{~m}$ high on average, with individual trees topping at $24 \mathrm{~m}$. Third-year results (February 2008) indicate that, although strip width significantly improved height growth (Table 2; $p=0.0049$ ), important differences remained between species $(p$ $<0.0001$ ), with strip width having the greatest effect on Diphysa robinioides followed by Dalbergia retusa. Although survival varied greatly between species, a common phenomenon in tropical EP plantations (Paquette et al. 2006b), it remained mostly unaffected by strip width, with a general but not significant tendency toward greater survival in larger strips ( $p=0.0811$; not presented). Survival was between $61 \%$ and $85 \%$ for Hymenea courbaril, Swetenia macrophyla, and D. retusa planted seedlings, whereas it was much lower for $D$. robinioides "stacas" (stakes, typically used for living fences) (36\%), harvested and planted the same day, and for transplanted Anacardium excelsum, of which only one survived $(2 \%)$. The transplants (natural seedlings found in the forest on the morning of the planting) were harvested fully leafed during the growing season, which probably explains the failure for that species. It is remarkable that although $D$. robinioides "stacas" had low survival, once established, the species showed the strongest growth among all species.

The overall mortality was further increased by two events: the construction of a road through the forest in 2006, as well as a fire that was started with the intention of clearing vegetation from a neighboring field but that accidentally entered the plantation (May 2007). Although many of the burned trees resprouted, with much reduced height growth, several died. The road and fire killed 18 additional trees (not included in the mortality analysis).

Tending was carried out primarily when we actively visited the plantation to evaluate it in March and June 2006, February and October 2007, and February 2008. The minimal amount of tending, combined with the 2007 fire, most likely contributed to somewhat lower height growth and survival ratios than expected. It is difficult for villagers to allocate scarce resources to the maintenance of the plantations. This first pilot project with a poor indigenous community did provide much insight into the necessary conditions for such projects to be successful. Most importantly, the projects must be explicitly included in CDM contracts in which tending duties are detailed and payments made after verification. Takimoto et al. (2008) had similar observations and underlined the importance of training and support, especially in the first years.

A protocol was, therefore, established for future projects on "parcelas" with comparable secondary forest. Strips $6 \mathrm{~m}$ wide are first cleared using machetes, separated by $6-\mathrm{m}$ strips of original vegetation left untouched, thus ensuring enough space for the development of crowns. Palms and trees of value for the community are preserved. Seedlings of alternating species are then planted every $3 \mathrm{~m}$ on two rows in the cleared strips, thus planting more than enough trees to account for mortality and the selection of the most productive and well-conformed individuals.

Tending is done by clearing all vegetation in a 1-m radius around young trees and removing all vegetation taller than the planted trees in the strips twice a year or more, depending on the amount of regrowth, for the first 2 to 4 years. This is common in tropical strip-planting literature (Ådjers et al. 1995, Peña-Claros et al. 2002). Competing vegetation in the planting strips is never allowed to 
Fig. 1. Cattle ranching has become the fastest-growing livelihood in Ipetí and elsewhere in Central America. Cattle ranching provides much-needed income to local populations and acts as easy-to-cash savings in rural communities with no access to credit. It is also a leading cause of deforestation in the area and contributes to global warming.

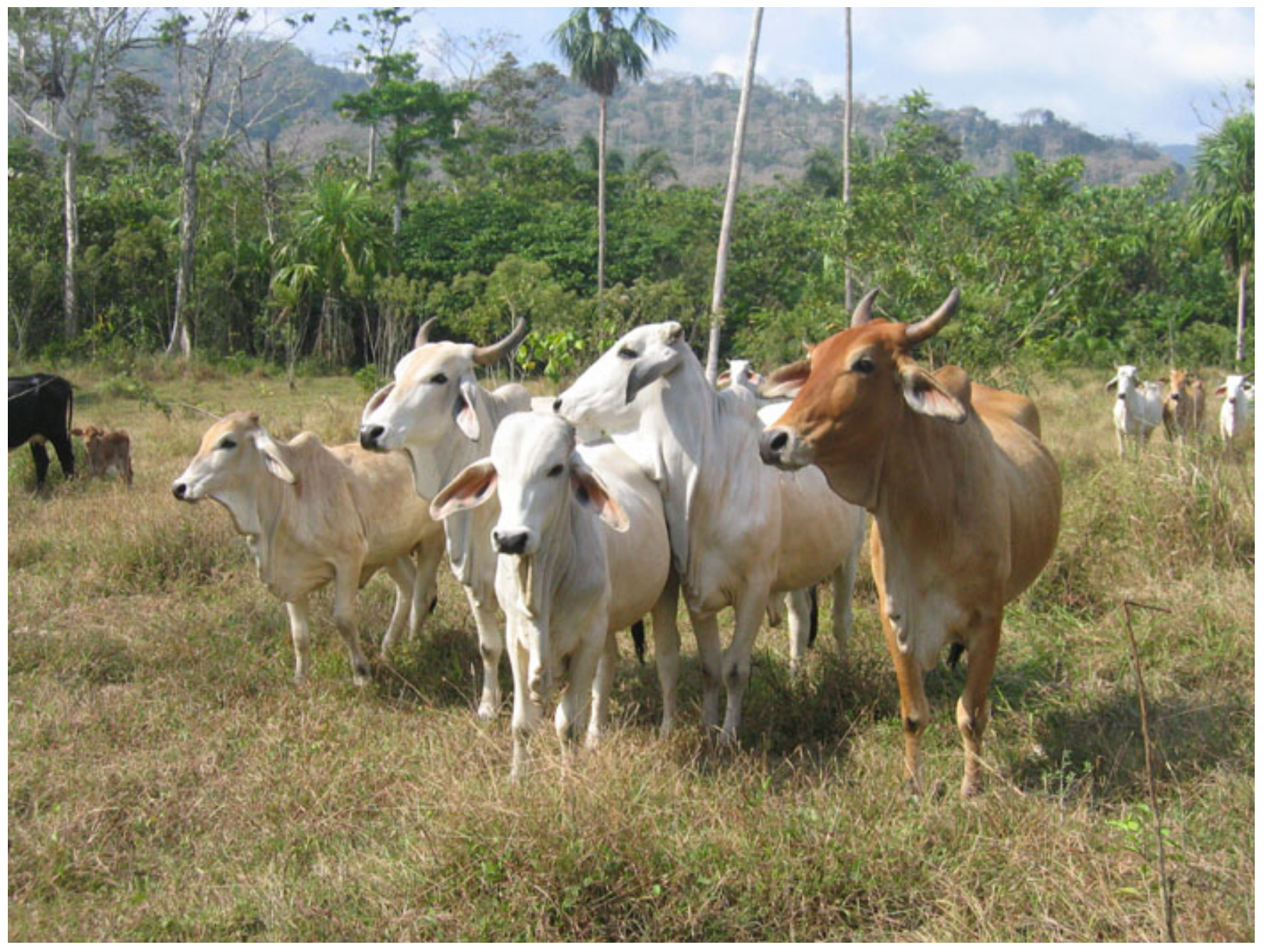

overtop the planted trees. Local people, especially the family members who own the "parcela" with the established plantation, are involved in all decisions and carry out the planting and tending duties.

\section{COMPARING CARBON STOCKS OF ALTERNATIVE LAND USES}

In the humid tropics, alternative land uses have been found to differ in terms of $\mathrm{C}$ stocks (Fig. 3). Kirby and Potvin (2007) found that forests store 57\% more $\mathrm{C}$ per hectare than agroforests and $86 \%$ more than pastures. This is particularly interesting given the fact that the forests surveyed would be considered "non-intact," as they are actively managed and selectively logged (albeit, at low intensity) for timber and non-timber forest products. The now common land use of pasture for cattle ranching provides negligible $\mathrm{C}$ storage, whereas agroforestry has intermediate $\mathrm{C}$ stocks (Table 3). Industrial teak plantations, which are extensively planted in 
Fig. 2. First enrichment-planting project in Ipetí (September 2005). The old fallow (secondary forest) is managed using the traditional strip-planting method. A 6-m strip is shown. Hemispherical inset (3-m strip) gives a sense of the vertical structure that is preserved.

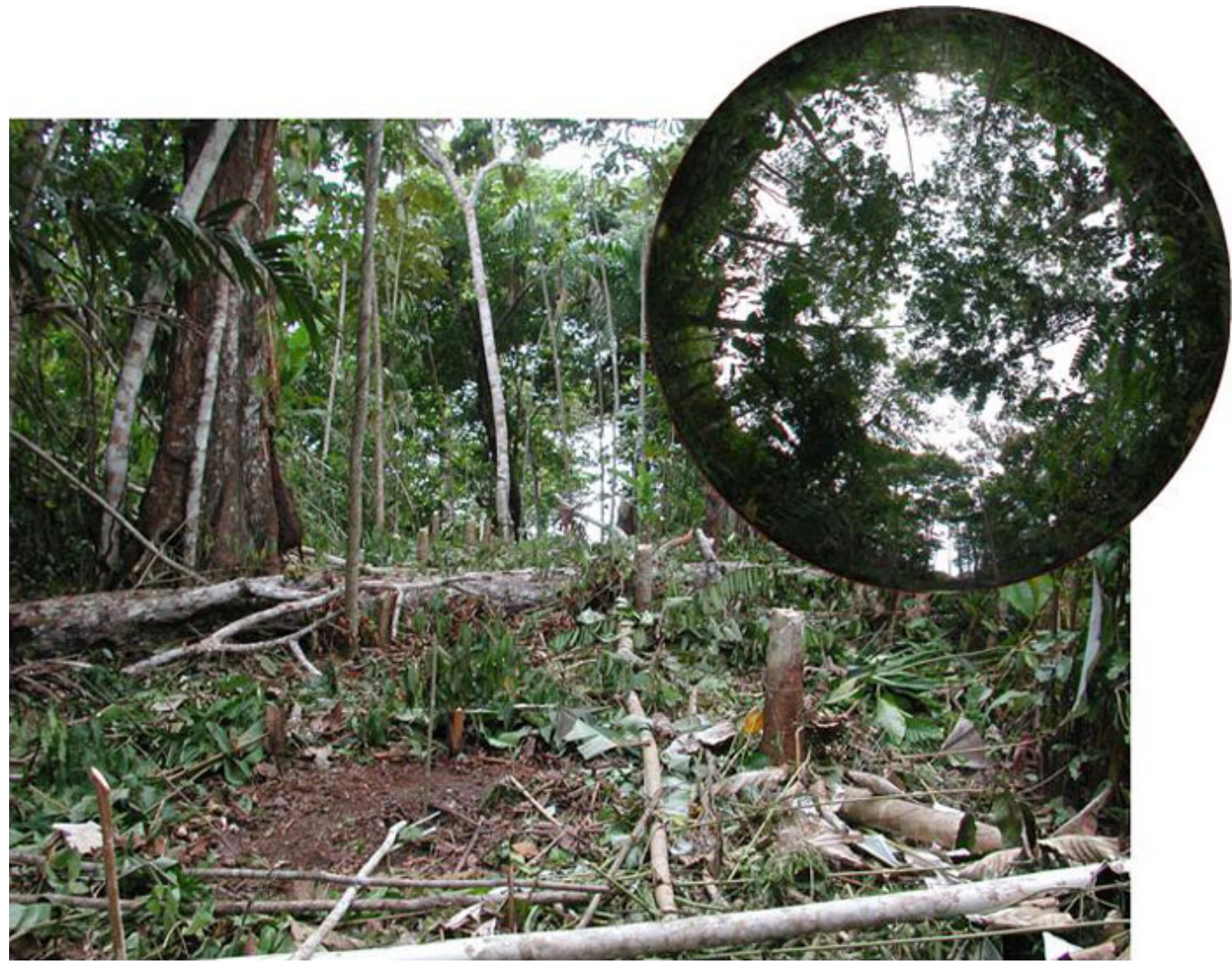

Central America, have substantial storage ability (Kraenzel et al. 2003; Fig. 3). Young native species plantations in Costa Rica and Panama are also already showing good storage potential, especially when mixed (Montagnini and Porras 1998, Potvin and Gotelli 2008).

Secondary forests have high rates of biomass productivity, especially during early succession (Silver et al. 2000), comparable to those of intensive tree plantations (Lugo 1997; Fig. 3). Aboveground biomass and $\mathrm{C}$ accumulation are positively correlated with time since abandonment (Hughes et al. 1999) (Table 3). In fact, secondary forests have been found to have greater potential for $\mathrm{C}$ sequestration, and larger $\mathrm{C}$ pools, than even primary forests (Lugo and Brown 1992, Marín-Spiotta et al. 2007).

Simple calculations suggest that EP in secondary forests could provide an interesting means of conserving $\mathrm{C}$ stocks. At establishment, the system 
Table 2. Third-year height of surviving trees (cm) (September 2005-February 2008) from the Ipetí plantation and ANOVA results.

\begin{tabular}{llllll}
\hline \hline & \multicolumn{7}{l}{ Strip width $(\mathrm{m})(p=0.0049)$} & & \\
Species $(p<0.0001)$ & 1 & 3 & 6 & Mean & Tukey HSD \\
\hline Dalbergia retusa & 87 & 150 & 238 & 164 & $\mathrm{~B}$ \\
Diphysa robinioides & 217 & 290 & 326 & 281 & $\mathrm{~A}$ \\
Hymenea courbaril & 71 & 86 & 102 & 89 & $\mathrm{C}$ \\
Swetenia macrophyla & 92 & 114 & 142 & 116 & $\mathrm{BC}$ \\
Mean & 101 & 155 & 183 & 149 & \\
\hline
\end{tabular}

Note: Two-level ANOVA $\mathrm{R}^{2}=0.38 ; p<0.0001 ; \mathrm{N}=117$. Width $\mathrm{x}$ species interaction not significant $(p$ $=0.4878$ ). Anacardium excelsum transplants had very high mortality and were not included in the analysis.

of strip planting would remove about half of the standing $\mathrm{C}$, leaving roughly $25 \mathrm{Mg} \mathrm{ha}^{-1}$ in the remaining stand (Table 3; secondary forests $\leq 20$ years). As the plantation matures, the matrix in the EP would also grow rapidly, stocking more C. At maturity, an EP would be constituted of half secondary forest (>40 years) and half plantation. Based on known available $C$ stocks from plantations and secondary forests, we estimated the $\mathrm{C}$ content of EP to be approximately $113 \mathrm{Mg} \mathrm{C} \mathrm{ha}^{-1}$ (Fig. 3; Table 3 ). This figure is conservative, as we could only find data for mature plantations of teak, and many of the species used in reforestation in Panama have greater wood density than teak (Wishnie et al. 2007). Furthermore, although it is reported that secondary forests can rapidly become as $\mathrm{C}$ rich as natural forests (Lugo and Brown 1992, MarínSpiotta et al. 2007), little data were available for C stocks of secondary forests older than 40 years. Quantitative data on EP, especially from the largescale and well-established projects, is needed to confirm these estimates.

Enrichment planting preserves the forested land that serves as the matrix between rows of planted trees, allowing this existing shelterwood to age naturally. Planting trees also enriches the land and improves its productivity, concentrating the primary production and storing $\mathrm{C}$ for the long term in highvalue, longer-living tree species. This is known to occur naturally in forests as part of succession (Kirby and Potvin 2007), as well as in plantations (Montagnini and Porras 1998), as some tree species naturally account for a disproportionate amount of $\mathrm{C}$ storage in both.

\section{GOING BEYOND CARBON}

In addition to $\mathrm{C}$ storage, alternative land uses can also be evaluated more holistically, looking at the services they provide (DeClerck et al. 2006), including biodiversity protection, improvement, or recovery (Parrotta 1995, Smith and Scherr 2003, Kirby and Potvin 2007), water quality and flow regulation, erosion, climate, and disease regulation (Bennett and Balvanera 2007, Foley et al. 2007). There are also many social services to consider, including cultural services, food and timber production (Bennett and Balvanera 2007), local 
Fig. 3. Aboveground ( $A B G)$ carbon storage of various land-use types in the humid tropics. Carbon storage is based on average rotation periods for each land-use type, i.e., the time over which carbon is stored. An average value was computed when more than one source was available (range represented with error bars). Enrichment-planting value was estimated from averaged teak monoculture plantation and secondary forest ( $>40$ years) values. Additional information, references and timescales available in Table 2.

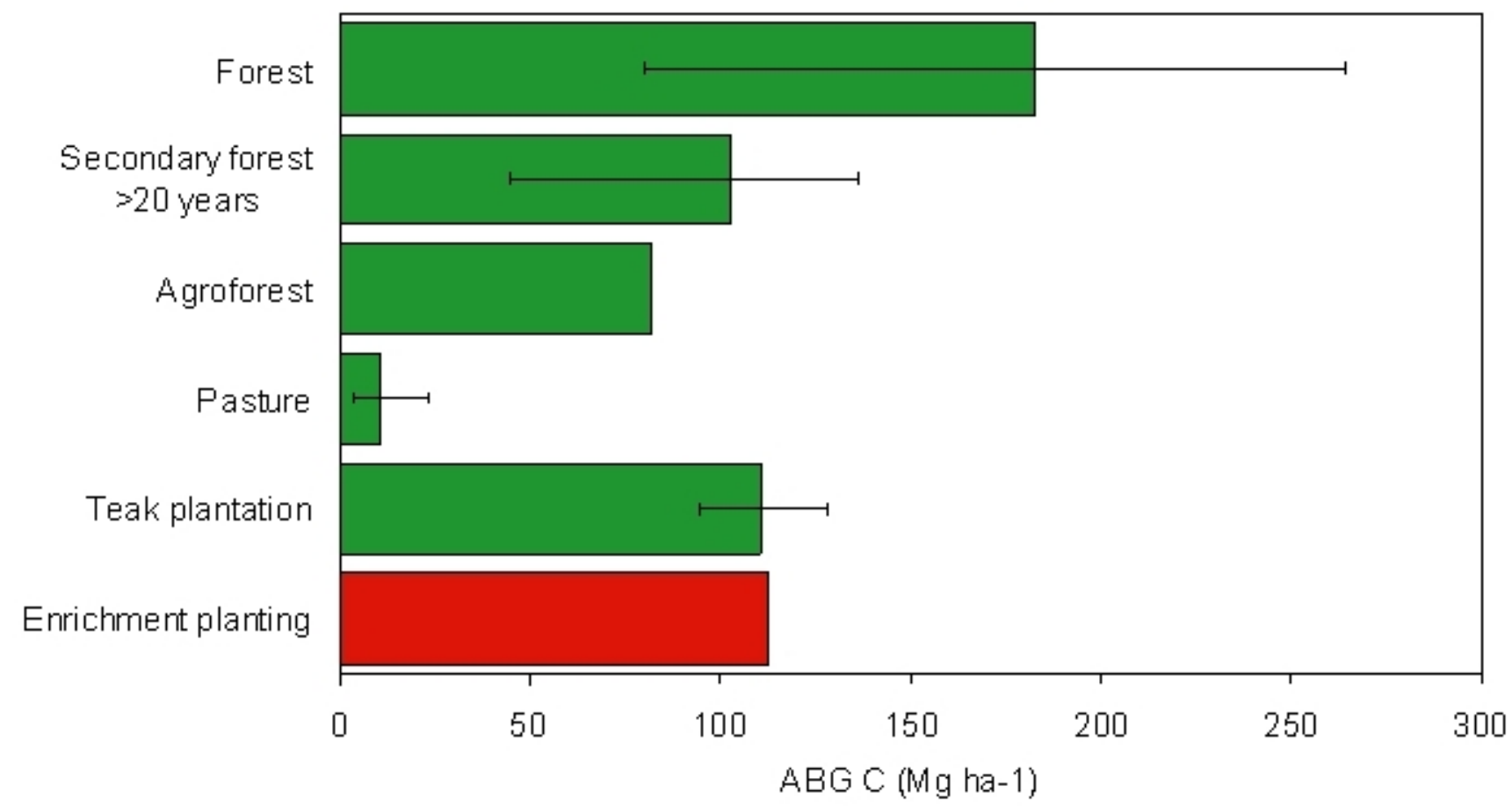

livelihood benefits (income and consumption), and influence of local people over land-management decisions (Smith and Scherr 2003).

Protected primary forest, being a natural system, provides optimal levels of all ecological services, hosting high biodiversity and robust regulating services (Bunker et al. 2005). It is closely followed by secondary forest, which also provides a range of services (Silver et al. 2000, Feldpausch et al. 2004, Roy Chowdhury 2007). Agroforest provides only limited biodiversity protection and regulating services, as it is an actively managed land use in which species are grown for human use. The clearcutting (or slash and burn) of forest for cattle ranching is a major cause of deforestation, thereby degrading biodiversity and regulating services of once-forested land. Similarly, teak plantations cause a suite of negative environmental impacts, as teak is normally intensively cultivated and monocropped (Lugo 1997, Healey and Gara 2003, Wishnie et al. 2007).

In terms of social services, the alternative land uses again vary substantially. Protected primary forest provides low social services, as it excludes human activity and management. In contrast, agroforest is a traditional land use and provides important cultural services for many indigenous people, subsistence consumption, the possibility of income generation, and full influence of local people over land-management decisions. Cattle ranching is an introduced practice: it provides no cultural services and excludes production of food or timber. It is, however, economically advantageous (Coomes et al. 2008). Similarly, teak monocultures provide no cultural services or food production. The social benefits come from the timber and income 
Table 3. Values, references, and timescales for aboveground (ABG) C storage for different land-use types in the humid tropics.

\begin{tabular}{|c|c|c|c|}
\hline Land-use type & $\mathrm{ABG} C\left(\mathrm{Mg} \mathrm{ha}^{-1}\right)$ & Source & Period (years) ${ }^{*}$ \\
\hline \multirow[t]{3}{*}{ Forest } & $80^{\dagger}$ & Marín-Spiotta et al. (2007) & \\
\hline & $172 ; 155 ; 191 ; 264^{\dagger}$ & Hughes et al. (2000) & \\
\hline & 235 & Kirby and Potvin (2007) & \\
\hline Agroforest & 82 & Kirby and Potvin (2007) & \\
\hline \multirow[t]{2}{*}{ Pasture } & $14 ; 23 ; 14 ; 4.4 ; 3.9 ; 3.1 ; 18^{\dagger}$ & Hughes et al. (2000) & \\
\hline & 4.2 & Kirby and Potvin (2007) & \\
\hline Teak plantation & $98 ; 128 ; 122 ; 94$ & Kraenzel et al. (2003) & 20 \\
\hline \multirow[t]{2}{*}{ Secondary forest } & $24 ; 62 ; 45 ; 83 ; 125^{\dagger}$ & Marín-Spiotta et al. (2007) & $10 ; 20 ; 30 ; 60 ; 80$ \\
\hline & $\begin{array}{l}2.1 ; 28 ; 17 ; 51 ; 11 ; 137 ; 41 ; 129 \\
104 ; 122 ; 136\end{array}$ & Hughes et al. (1999) & $\begin{array}{l}0.5 ; 4 ; 8 ; 8 ; 10 ; 16 ; 20 ; 20 ; 26 ; \\
30 ; 50\end{array}$ \\
\hline $\begin{array}{l}\text { Enrichment } \\
\text { planting }\end{array}$ & 113 & Our estimate & $\begin{array}{l}\text { Planted trees: } 20 \\
\text { Sec. forest: }>40\end{array}$ \\
\hline
\end{tabular}

* Forest, agroforest, and pasture assumed to hold a constant quantity of C.

$\uparrow \mathrm{C}$ content calculated from biomass and ratio of $\mathrm{C}$ content.

production. However, financial security is low, because income is only generated at harvest age of 20 years or so.

The shifting nature of tropical land use may mean that the high C-mitigating capacity of secondary forest is temporary. Carbon-offset projects using EP could provide incentives to protect secondary forest and harness its $\mathrm{C}$-sequestration capacity more permanently. Such projects could also introduce social benefits that are lacking in protected forest. In terms of ecological services, EP provides biodiversity recovery and improvement by reintroducing native species, allowing growth of the shelterwood, and providing restored natural habitat for wildlife (Berger 1993, Parrotta 1995, Gullison et al. 2007). In fact, many tree species native to Panama have the potential to become high-quality timber, but may perform better in a shaded environment than in open plantations (Wishnie et al. 2007). In addition, many high-quality timber species also have disproportionate $\mathrm{C}$ storage capacity (Foley et al. 2007, Kirby and Potvin 2007). Shelterwood may also improve the height growth and trunk shape by maintaining the vertical structure of the forest (Schütz 2001, Wishnie et al. 2007). These are important attributes for timber because trees not only sequester more $\mathrm{C}$, but also produce valuable timber that can be harvested to produce furniture, housing, and other long-lasting products in which $\mathrm{C}$ will remain stored. The Face Foundation projects are good examples of how EP can be used 
to restore degraded forest while providing protection to the landscape through the voluntary $\mathrm{C}$ market (Bebber et al. 2002, Butler 2007, Wunder and Albán 2008). In the context of developing countries' need for economic growth we believe that EP could provide a better ecological alternative than monoculture planting, which has been recently advocated in the context of increased protection of tropical forests (Cyranoski 2007).

Because of the many species planted and the conservation of the matrix, EP makes for a highly diversified plantation system compared with typical row plantations, especially monocultures. Although the ecological benefits are obvious, recent debates also suggest that such systems may also be more productive (DeClerck et al. 2006), through facilitation (Brooker et al. 2008) and optimal use of ecological niches, a process known as complementarity (Erskine et al. 2006, Kelty 2006). There is also increasing interest in evaluating the potential role of species diversity in promoting ecosystem services and resiliencies (Loreau et al. 2001, Cardinale et al. 2006). Some positive effects of biodiversity in tropical plantations have already been demonstrated (Montagnini and Porras 1998, Piotto et al. 2004, Potvin and Gotelli 2008).

It seems clear that EP can provide substantial social services. The trees planted are culturally significant and chosen by the local people who will provide for their care. The local participants have strong influence over land-management decisions and retain control over the land, an important issue in current debates (Gullison et al. 2007, Michon et al. 2007). Highly valuable timber or non-timber products can be sold or used locally for construction or artisanal products sold at markets (e.g., "cocobolo" carvings) (Velásquez Runk et al. 2004). Furthermore, EP generates income in that the landholders are compensated for management under both CDM protocols or the voluntary market, a recognized option to sustain viable forestry practices in pressured forests (Gullison et al. 2007, Ibarra Gené 2007).

This method provides promising ecological, social, and economic benefits compared with other landuse types such as monoculture plantations and cattle ranching. Such plantings can favor the conservation of the enriched secondary forest (Dalle et al. 2006). The potential of EP is further increased by its excellent $\mathrm{C}$ storage potentials, high involvement of local people, and low initialization and transaction costs in the context of A/R AMS. Overall, EP may be a viable option for either the voluntary $\mathrm{C}$ market or for $\mathrm{A} / \mathrm{R} \mathrm{CDM}$ and may allow increased implementation of such valuable projects.

\section{CONCLUSION}

Carbon stocks in Ipetí and elsewhere in the tropics are already decreasing, as forest land is being cleared for land-intensive economic activities like cattle ranching (Potvin et al. 2007b). Enrichment planting, on the other hand, protects existing stands and associated ecological services and enriches them with valuable species. It brings value to degraded forest making it worth maintaining rather than further degrading it by turning it into pasture for cattle. This effect was demonstrated elsewhere, e.g., in the Maya Zone of Quintana Roo, Mexico ("Plan Piloto Forestal;"' Dalle et al. 2006). With global climate change, continuing rapid tropical deforestation, and the compromised economic state of many developing countries, it is necessary to find feasible and effective alternatives to current $A / R$ CDM options that are consistent with the livelihoods of local partakers. Enrichment planting, as it has been presented in this paper, is one such alternative.

Enrichment planting can also accelerate the return of a productive forest capable of sustaining economic and social activities of small poor communities, thus diminishing pressure on primary forests. In order for EP to be used for C-offsetting projects, more data are needed, especially from the older, large-scale projects now in place. We also need REDD, A/R CDM, voluntary C markets, and PES credits to be admissible for such projects carried out in secondary forests, so as to make them attractive for small-scale producers and offer them the support needed to achieve conservation, production of services, and sequestration objectives.

We have been working in Ipetí-Emberá almost continuously since 1997. The work done with the community raised awareness of environmental degradation and motivated a search for land-use alternatives. This openness to technological innovation almost certainly helped the community adopt EP as a legitimate land use. The extent to which EP may be applied successfully in other social contexts remains to be determined. We propose that EP might be especially interesting for indigenous communities because they, traditionally, have stronger cultural ties with forested landscape 
than with pasture. It would be interesting to replicate the experiment in other indigenous and nonindigenous communities to see how robust the benefits that we identified really are.

Responses to this article can be read online at: http://www.ecologyandsociety.org/voll4/iss 1/art31/ responses/

\section{Acknowledgments:}

The authors wish to express their deepest thanks to the community of Ipeti-Emberá. Other thanks to $M$. Boenke, J. L. Bonilla, G. U. Cabrera, S. Hutchinson, R. Ibáñez, O. Ramos, and to J. Hall and the staff at PRORENA for their help. This work was carried out in part by J. H. and A. V. S. as a requirement for the McGill Panama Field Study Semester. NSERC financial support to C. P. andA. P. is acknowledged.

\section{LITERATURE CITED}

Ådjers, G., S. Hadengganan, J. Kuusipalo, K. Nuryanto, and L. Vesa. 1995. Enrichment planting of dipterocarps in logged-over secondary forests: effect of width, direction and maintenance method of planting line on selected Shorea species. Forest Ecology and Management 73(1-3):259-270.

Aide, T. M., J. K. Zimmerman, J. B. Pascarella, L. Rivera, and H. Marcano-Vega. 2000. Forest regeneration in a chronosequence of tropical abandoned pastures: implications for restoration ecology. Restoration Ecology 8(4):328-338.

Ashton, M. S., and C. M. Peters. 1999. Even-aged silviculture in tropical rainforests of Asia: lessons learned and myths perpetuated. Journal of Forestry 97(11):14-19.

Bebber, D., N. Brown, M. Speight, P. MouraCosta, and Y. S. Wai. 2002. Spatial structure of light and dipterocarp seedling growth in a tropical secondary forest. Forest Ecology and Management 157(1-3):65-75.

Bennett, E. M., and P. Balvanera. 2007. The future of production systems in a globalized world. Frontiers in Ecology and the Environment 5 (4):191-198.
Berger, J. J. 1993. Ecological restoration and nonindigenous plant species: a review. Restoration Ecology 1(2):74-82.

Brooker, R. W., F. T. Maestre, R. M. Callaway, C. L. Lortie, L. A. Cavieres, G. Kunstler, P. Liancourt, K. Tielbörger, J. M. J. Travis, F. Anthelme, C. Armas, L. Coll, E. Crocket, S. Delzon, E. Forey, Z. Kikvidze, J. Olofsson, F. Pugnaire, C. L. Quiroz, P. Saccone, K. Schiffers, M. Seifan, B. Touzard, and R. Michalet. 2008. Facilitation in plant communities: the past, the present and the future. Journal of Ecology 96(1):1834.

Bunker, D. E., F. DeClerck, J. C. Bradford, R. K. Colwell, I. Perfecto, O. L. Phillips, M. Sankaran, and S. Naeem. 2005. Species loss and aboveground carbon storage in a tropical forest. Science $\mathbf{3 1 0}$ (5750):1029-1031.

Butler, R. A. 2007. Tropical rainforests: saving what remains. Increasing productivity and rehabilitating degraded habitat. Mongabay.com, San Francisco, California, USA. [online] URL: htt p://rainforests.mongabay.com/1014.htm.

Cardinale, B. J., D. S. Srivastava, J. Emmett Duffy, J. P. Wright, A. L. Downing, M. Sankaran, and C. Jouseau. 2006. Effects of biodiversity on the functioning of trophic groups and ecosystems. Nature 443(7114):989-992.

Coomes, O. T., F. Grimard, C. Potvin, and P. Sima. 2008. Commentary. The fate of the tropical forest: carbon or cattle? Ecological Economics $\mathbf{6 5}$ (2):207-212.

Cyranoski, D. 2007. Logging: the new conservation. Nature 446(7136):608-610.

Dalle, S. P., S. de Blois, J. Caballero, and T. Johns. 2006. Integrating analyses of local land-use regulations, cultural perceptions and land-use/land cover data for assessing the success of communitybased conservation. Forest Ecology and Management 222(1-3):370-383.

Davidson, R., Y. Mauffette, and D. Gagnon. 2002. Light requirements of seedlings: a method for selecting tropical trees for plantation forestry. Basic and Applied Ecology 3(3):209-220.

DeClerck, F., J. C. Ingram, and C. M. Rumbaitis del Rio. 2006. The role of ecological theory and 
practice in poverty alleviation and environmental conservation. Frontiers in Ecology and the Environment 4(10):533-540.

Dirzo, R., and P. H. Raven. 2003. Global state of biodiversity and loss. Annual Review of Environment and Resources 28:137-167.

Erskine, P. D., D. Lamb, and M. Bristow. 2006. Tree species diversity and ecosystem function: can tropical multi-species plantations generate greater productivity? Forest Ecology and Management 233 (2-3):205-210.

Feldpausch, T. R., M. A. Rondon, E. C. M. Fernandes, S. J. Riha, and E. Wandelli. 2004. Carbon and nutrient accumulation in secondary forests regenerating on pastures in central Amazonia. Ecological Applications 14(4):S164S176.

Foley, J. A., G. P. Asner, M. H. Costa, M. T. Coe, R. DeFries, H. K. Gibbs, E. A. Howard, S. Olson, J. Patz, N. Ramankutty, and P. Snyder. 2007. Amazonia revealed: forest degradation and loss of ecosystem goods and services in the Amazon Basin. Frontiers in Ecology and the Environment 5(1):2532.

Gullison, R. E., P. C. Frumhoff, J. G. Canadell, C. B. Field, D. C. Nepstad, K. Hayhoe, R. Avissar, L. M. Curran, P. Friedlingstein, C. D. Jones, and C. Nobre. 2007. Tropical forests and climate policy. Science 316(5827):985-986.

Hansen, A. J., W. C. McComb, R. Vega, M. G. Raphael, and M. Hunter. 1995. Bird habitat relationships in natural and managed forests in the west Cascades of Oregon. Ecological Applications 5(3):555-569.

Healey, S. P., and R. I. Gara. 2003. The effect of a teak (Tectona grandis) plantation on the establishment of native species in an abandoned pasture in Costa Rica. Forest Ecology and Management 176(1-3):497-507.

Houghton, R. A. 2005. Aboveground forest biomass and the global carbon balance. Global Change Biology 11(6):945-958.

Hughes, R. F., J. B. Kauffman, and V. J. Jaramillo. 1999. Biomass, carbon, and nutrient dynamics of secondary forests in a humid tropical region of México. Ecology 80(6):1892-1907.

Hughes, R. F., J. B. Kauffman, and V. J. Jaramillo. 2000. Ecosystem-scale impacts of deforestation and land use in a humid tropical region of Mexico. Ecological Applications 10(2):515-527.

Ibarra Gené, E. 2007. The profitability of forest protection versus logging and the role of payments for environmental services (PES) in the Reserva Forestal Golfo Dulce, Costa Rica. Forest Policy and Economics 10(1-2):7-13.

Intergovernmental Panel on Climate Change (IPCC). 2001. Climate change 2001: the scientific basis. Contribution of working group I to the third assessment report of the IPCC. Cambridge University Press, Cambridge, UK.

International Tropical Timber Organization (ITTO). 2002. ITTO guidelines for the restoration, management and rehabilitation of degraded and secondary tropical forests. ITTO Policy Development Series No 13, ITTO, Yokohama, Japan.

Kelty, M. J. 2006. The role of species mixtures in plantation forestry. Forest Ecology and Management 233(2-3):195-204.

Kirby, K. R., and C. Potvin. 2007. Variation in carbon storage among tree species: implications for the management of a small-scale carbon sink project. Forest Ecology and Management 246(23):208-221.

Kraenzel, M., A. Castillo, T. Moore, and C. Potvin. 2003. Carbon storage of harvest-age teak (Tectona grandis) plantations, Panama. Forest Ecology and Management 173(1-3):213-225.

Locatelli, B., V. Rojas, and Z. Salinas. 2008. Impacts of payments for environmental services on local development in northern Costa Rica: a fuzzy multi-criteria analysis. Forest Policy and Economics 10(5):275-285.

Loreau, M., S. Naeem, P. Inchausti, J. Bengtsson, J. P. Grime, A. Hector, D. U. Hooper, M. A. Huston, D. Raffaelli, B. Schmid, D. Tilman, and D. A. Wardle. 2001. Biodiversity and ecosystem functioning: current knowledge and future challenges. Science 294(5543):804. 
Lugo, A. E. 1997. The apparent paradox of reestablishing species richness on degraded lands with tree monocultures. Forest Ecology and Management 99(1-2):9-19.

Lugo, A. E., and S. Brown. 1992. Tropical forests as sinks of atmospheric carbon. Forest Ecology and Management 54(1-4):239-255.

Marín-Spiotta, E., W. L. Silver, and R. Ostertag. 2007. Long-term patterns in tropical reforestation: plant community composition and aboveground biomass accumulation. Ecological Applications 17 (3):828-839.

Martinez-Garza, C., and H. F. Howe. 2003. Restoring tropical diversity: beating the time tax on species loss. Journal of Applied Ecology 40(3):423429.

McComb, W., T. Spies, and W. Emmingham. 1993. Douglas-fir forests: managing for timber and wildlife habitats. Journal of Forestry 91(12):31-42.

Michon, G., P. Levang, and F. Verdeaux. 2007. Domestic forests: a new paradigm for integrating local communities' forestry into tropical forest science. Ecology and Society 12(2): 1. [online] URL: http://www.ecologyandsociety.org/vol12/iss2/ art1/.

Minang, P., M. McCall, M. Skutsch, and J. Verplanke. 2008. A data support infrastructure for clean development mechanism forestry implementation: an inventory perspective from Cameroon. Mitigation and Adaptation Strategies for Global Change 13(2):157-178.

Montagnini, F., B. Eibl, L. Grance, D. Maiocco, and D. Nozzi. 1997. Enrichment planting in overexploited subtropical forests of the Paranaense region of Misiones, Argentina. Forest Ecology and Management 99(1-2):237-246.

Montagnini, F., and C. Porras. 1998. Evaluating the role of plantations as carbon sinks: an example of an integrative approach from the humid tropics. Environmental Management 22(3):459-470.

Pagiola, S., E. Ramírez, J. Gobbi, C. de Haan, M. Ibrahim, E. Murgueitio, and J. P. Ruíz. 2007. Paying for the environmental services of silvopastoral practices in Nicaragua. Ecological Economics 64(2):374-385.

Paquette, A., A. Bouchard, and A. Cogliastro. 2006a. Successful under-planting of red oak and black cherry in early-successional deciduous shelterwoods of North America. Annals of Forest Science 63(8):823-831.

Paquette, A., A. Bouchard, and A. Cogliastro. 2006b. Survival and growth of under-planted trees: a meta-analysis across four biomes. Ecological Applications 16(4):1575-1589.

Parrotta, J. A. 1995. Influence of overstory composition on understory colonization by native species in plantations on a degraded tropical site. Journal of Vegetation Science 6(5):627-636.

Pearson, T., S. Walker, and S. Brown. 2006. Guidebook for the formulation of afforestation and reforestation projects under the clean development mechanism. International Tropical Timber Organization (ITTO), Yokohama, Japan.

Peña-Claros, M., R. G. A. Boot, J. Dorado-Lora, and A. Zonta. 2002. Enrichment planting of Bertholletia excelsa in secondary forest in the Bolivian Amazon: effect of cutting line width on survival, growth and crown traits. Forest Ecology and Management 161(1-3):159-168.

Piotto, D., E. Víquez, F. Montagnini, and M. Kanninen. 2004. Pure and mixed forest plantations with native species of the dry tropics of Costa Rica: a comparison of growth and productivity. Forest Ecology and Management 190(2-3):359-372.

Potvin, C., and A. Bovarnick. 2008. Reducing emissions from deforestation and forest degradation in developing countries: key actors, negotiations and actions. Carbon and Climate Law Review 2008 (3):264-272.

Potvin, C., O. T. Coomes, and F. Grimard. 2007a. Will RED work where it should? Science E-Letter responses. [online] URL: http://www.sciencemag.org/ cgi/eletters/316/5827/5985.

Potvin, C., and N. J. Gotelli. 2008. Biodiversity enhances individual performance but does not affect survivorship in tropical trees. Ecology Letters 11 (3):217-223. 
Potvin, C., P. Tschakert, F. Lebel, K. Kirby, H. Barrios, J. Bocariza, J. Caisamo, L. Caisamo, C. Cansari, J. Casamá, M. Casamá, L. Chamorra, N. Dumasa, S. Goldenberg, V. Guainora, P. Hayes, T. Moore, and J. Ruíz. 2007b. A participatory approach to the establishment of a baseline scenario for a reforestation clean development mechanism project. Mitigation and Adaptation Strategies for Global Change 12 (8):1341-1362.

Romell, E., G. Hallsby, A. Karlsson, and C. Garcia. 2008. Artificial canopy gaps in a Macaranga spp. dominated secondary tropical rain forest-effects on survival and above ground increment of four under-planted dipterocarp species. Forest Ecology and Management 255(56):1452-1460.

Roy Chowdhury, R. 2007. Household land management and biodiversity: secondary succession in a forest-agriculture mosaic in southern Mexico. Ecology and Society 12(2): 31. [online] URL: http: //www.ecologyandsociety.org/vol12/iss2/art31/.

Schulze, M. 2008. Technical and financial analysis of enrichment planting in logging gaps as a potential component of forest management in the eastern Amazon. Forest Ecology and Management 255(34):866-879.

Schütz, J.-P. 2001. Opportunities and strategies of transforming regular forests to irregular forests. Forest Ecology and Management 151(1-3):87-94.

Silver, W. L., R. Ostertag, and A. E. Lugo. 2000. The potential for carbon sequestration through reforestation of abandoned tropical agricultural and pasture lands. Restoration Ecology 8(4):394-407.

Smith, J., K. Mulongoy, and J. Sayer. 2000. Harnessing carbon markets for tropical forest conservation: towards a more realistic assessment. Environmental Conservation 27(3):300-311.

Smith, J., and S. J. Scherr. 2003. Capturing the value of forest carbon for local livelihoods. World Development 31(12):2143-2160.

Stern, N. 2007. The economics of climate change: the Stern review. Cambridge University Press, Cambridge, UK.
Suyanto, S., N. Khususiyah, and B. Leimona. 2007. Poverty and environmental services: case study in Way Besai watershed, Lampung Province, Indonesia. Ecology and Society 12(2): 13. [online] URL: http://www.ecologyandsociety.org/vol12/iss2/ $\underline{\operatorname{art13}}$.

Takimoto, A., P. K. R. Nair, and J. R. R. Alavalapati. 2008. Socioeconomic potential of carbon sequestration through agroforestry in the West African Sahel. Mitigation and Adaptation Strategies for Global Change 13(7):745-761.

Tschakert, P., O. T. Coomes, and C. Potvin. 2007. Indigenous livelihoods, slash-and-burn agriculture, and carbon stocks in eastern Panama. Ecological Economics 60(4):807-820.

United Nations Framework Convention on Climate Change (UNFCCC). 2006. Simplified baseline and monitoring methodologies for selected $A / R$ Small-Scale CDM project activity categories. UNFCC Small-Scale Working Group, Bonn, Germany.

2007. Kyoto protocol reference manual on accounting of emissions and assigned amounts. United Nations Framework Convention on Climate Change - Secretariat, Bonn, Germany.

Velásquez Runk, J., P. Mepaquito, and F. Peña. 2004. Artisanal non-timber forest products in Darién Province, Panamá: the importance of context. Conservation and Society 2(2):217-234.

Wishnie, M. H.,D.H. Dent, E. Mariscal, J. Deago, N. Cedeño, D. Ibarra, R. Condit, and P. M. S. Ashton. 2007. Initial performance and reforestation potential of 24 tropical tree species planted across a precipitation gradient in the Republic of Panama. Forest Ecology and Management 243(1):39-49.

Wunder, S. 2006. Are direct payments for environmental services spelling doom for sustainable forest management in the tropics? Ecology and Society 11(2): 23. [online] URL: http: //www.ecologyandsociety.org/vol11/iss2/art23/.

Wunder, S., and M. Albán. 2008. Decentralized payments for environmental services: the cases of Pimampiro and PROFAFOR in Ecuador. Ecological Economics 65(4):685-698. 